\title{
Corporate Governance Quality: Vietnam Needs to Implement Economics, Business and Geopolitics University Courses
}

\author{
Tran Thi Hong Lien
}

Published online: 10 November 2012

(C) CEEUN 2012

\begin{abstract}
To assess corporate governance quality is the need of most board directors and other stakeholders, since such assessment is good foundation for next improvement plans. In an effort to meet such demand, this article will introduce 2011-assessment of corporate governance quality of companies listed in Hanoi stock exchange (HNX) based on Gov-score criteria. The findings from a two-step survey show that corporate governance quality of HNX companies is at medium level (25.73/51), only meets minimum requirements by current legal provisions. To raise the corporate governance quality, the author suggests two solutions. The first is to consider framework improvement the leverage for enhancing corporate governance quality at company level, and the second is to promote corporate governance education for all related groups. The second solution will be most effective if it is targeted at business undergraduate students to enable them understand why corporate governance right from their career start, so we suggest to incorporate the subject as an important course for business undergraduate students in their final school year.
\end{abstract}

Keywords Corporate governance $\cdot$ Corporate governance quality $\cdot$ Listed companies · Hanoi stock exchange - Corporate governance education

\section{Introduction of Corporate Governance Studies in Vietnam}

In Vietnam, corporate governance is not a new domain; it was raised at the time OECD, Worldbank and IFC introduced corporate governance principles into the country. Most recently, at the end of 2010, the IFC launched the Vietnam Corporate Governance Scorecard as a review of corporate governance practices in the one

T. T. H. Lien $(\bowtie)$

University of Economics and Law, Vietnam National University - Ho Chi Minh City,

Ho Chi Minh City, Vietnam

e-mail: lientth@uel.edu.vn 
hundred biggest listed companies based on the OECD principles. The scorecard has been measured for consecutive 2 years of 2009 and 2010.

In 2006, World Bank announced a Report on the Observance of Standards and Codes (ROSC) in Vietnam. It described current practice and provided policy recommendations in six areas: (i) corporate governance framework; (ii) rights of shareholders; (iii) equitable treatment of shareholders; (iv) role of stakeholders in corporate governance; (v) disclosure and transparency; and (vi) responsibilities of the Board. The report shows that Vietnam has taken important steps to establish its corporate governance framework. There remain, however, some significant challenges moving forward. These include ensuring implementation of recent legislative changes, strengthening the capacity of the securities market regulator, bolstering enforcement of regulatory compliance, setting the framework and standards for the informal securities market, promoting awareness and training of corporate directors on corporate governance, and encouraging better quality, timely, and accessible information (World Bank 2006). Thus, assessment and suggestions in ROSC focused on the national legal framework for corporate governance.

In 2008, Lien (the author) completed her master dissertation titled «The impact of corporate governance on corporate performance». In addition to a general introduction of corporate governance, the dissertation introduced methods for the assessment of the impact on the world (for example the methods using CGI, G-Index, Entrenchment Index, Gov-Score), analyzed strengths and weaknesses of each method and recommended using Gov-Score index to test the case of VietnamItaly Steel Joint Stock Company. The analysis shows that the eight criteria groups of Gov-Score were suitable with the legal framework and practices in corporate governance in Vietnam, and they would be more suitable after improvement (Lien 2008).

Thus, the main researches on corporate governance in Vietnam mainly focus on the national corporate governance framework. However, the author and her colleagues have made beginning steps in the assessment of corporate governance quality at company level.

Corporate governance includes mechanisms, structures and processes that regulate the relationships between shareholders/owners, management board and other stakeholders through which the company is best managed and controlled (Lien 2008). It is different from corporate management that focuses on operations activities such as finance, marketing, human resource or sales, etc.

Corporate governance quality is the totality of the system of mechanisms, structures and processes that regulate the relationships between shareholders/owners, management board and other stakeholders in order to ensure that the company is well managed and meets the goals of the shareholders (Hai and Lien 2012). Corporate quality assessment systems have been developed for more than 10 years and each inherits some elements from the others. Each of TLC, GMI, S\&P CGS or Deminor indice includes from 100 to 1,100 criteria and mostly focuses on financial aspects of companies. G-Index and Entrenchment Index both are based on IRRC (Investor Responsibility Research Center) criteria of anti-takeover measures and focus on managing external factors. CGI or CGQ both are based on data of ISS (Institutional 
Shareholders Services) with many criteria that are not stable and can be changed for each subject in measurement.

Gov-Score index was devised by Lawrence D. Brown and Marcus L. Caylor in 2005. This is a composite index that includes 51 factors belonging to eight groups based on ISS's data. The criteria are defined in "ISS Corporate Governance: Best Practices User Guide and Glossary" (ISS 2003). The factor groups include audit, board, charter/bylaws, director education, executive and director compensation, ownership, progressive practices and incorporation (JCGR 2003). Brown and Caylor (2006) give 51 corporate governance factors binominal values of either 1 or 0 depending on whether the criterium meets the acceptable minimum requirements or not. In theory, Gov-score ranges from 0 to 51. However, tests with many samples show a practical range of Gov-Score from 13 to 37. Brown and Caylor consider Gov-Score a good representative for corporate governance quality; since companies with higher Gov-scores show higher performance and market values and pay more for shareholders. This relation is consent with prediction of agency theory. Gov-score have been used by other researchers and their research results show similar results, therefore, the author uses Gov-score to test the case of Vietnam.

\section{An Assessment of Corporate Governance Quality of Companies in Vietnam Using Gov-Score Method}

Data and Hypotheses

The assessment presented here is the outcome of a survey in 2011. The survey was conducted on all companies listed in Hanoi stock exchange (HNX) (one of two stock exchanges in Vietnam, the other is Ho Chi Minh Stock Exchange-HSX) (396 companies) in order to give the broadest overview of corporate governance activities of these companies. The survey was divided into two steps.

Step 1 A general review of corporate governance situation of the 396 companies was made based on published materials including

(1) Company charters

(2) 2010 annual reports

(3) 2010 corporate governance reports

These are three primary documents that record all facets of corporate governance. Besides, the survey exploited general shareholder meeting resolutions, board resolutions, corporate governance bylaws and financial reports that supplement information omitted in the primary reports.

Under current regulations, listed companies have to submit the reports to the State Securities Commission (SSC), Exchanges (HNX or HSX), Vietnam Securities Depository (VSD) and corporate media (website for instance). To exactly assess the current situation of corporate governance at company level, the author collected data from the official corporate websites, because that type of publication shows the highest proactiveness and voluntariness of companies in corporate governance. 


\section{Step 2}

After the general review, the author specified companies with full three reports. This group included forty-nine companies. The forty-nine companies are good representatives for all companies because:

First, information published on corporate websites represents the highest voluntariness of companies in disclosure, and this is the most reliable indicator of corporate governance, not the compulsory reports to SSC, HNX and VSD. Corporate governance is only good when it originates from the internal needs of shareholders and companies.

Second, information is kept for a longer time in corporate websites than in other websites. Corporate governance reports are usually completed and published at the end of April annually. In addition, corporate websites are especially useful for searching for information from previous-years.

Each company in this group is equivalent to a questionnaire designed based on Gov-score criteria. The questionnaire includes 51 primary questions and 78 subquestions.

The survey data were used to test four hypotheses, of which three are described below.

$\mathrm{H} 1$ : Corporate governance quality of companies listed in Hanoi stock exchange is at medium level on Gov-score scale.

$\mathrm{H} 2$ : There is a high similarity among the listed companies in implementing a number of Gov-score criteria.

H3: The companies listed in Hanoi stock exchange have not implemented many progressive practices that go beyond current regulations recommended in the Model Charter for listed companies.

\section{Results and Discussion}

Testing $\mathrm{Hl}$ Corporate governance quality of companies listed in Hanoi stock exchange is at medium level on Gov-Score scale.

Table 1 shows that 34 companies had not established their own website. Among the 362 companies with websites, 54 did not publish corporate governance information therein. A noticeable point is that more than a quarter (equivalent to 107 companies) possessed website addresses that were not identical to what disclosed by HNX. This is a barrier to shareholders and investors who want to find corporate information but are not good at basic computer and searching skills. Those people are not ready and may not know how to search for official corporate websites via search tools.

In the case of companies publishing corporate governance information on their websites, the search was not easy because the information was structured in an inconvenient way for users. In general, companies organized an item titled "Shareholders/Investors" on the website; this item included sub-items such as "Charter/Bylaws", "Financial Reports", "Annual Reports", "Annual General Shareholders Meeting Resolutions"; "Board of Directors Resolutions"; "Corporate Governance Reports" and "Transaction Information" etc. Many other companies 
Table 1 Current corporate website usage for corporate governance disclosure by companies listed in HNX

Source: Hai and Lien (2012)

\begin{tabular}{lll}
\hline Order & Criteria & $\begin{array}{l}\text { Number of HNX } \\
\text { companies }\end{array}$ \\
\hline 1 & Have no corporate website & 34 \\
2 & Have a corporate website & 362 \\
3 & Have a corporate website without & 54 \\
& corporate governance information & 107 \\
4 & $\begin{array}{l}\text { Have a corporate website address that is } \\
\text { not identical as presented in Hanoi }\end{array}$ \\
& $\begin{array}{l}\text { stock exchange's disclosure } \\
\end{array}$
\end{tabular}

Table 2 Statistics of report disclosure on corporate websites in 2010

\begin{tabular}{lrrrr}
\hline Number of report disclosed & 0 & 1 & 2 & 3 \\
Number of HNX companies & 171 & 101 & 75 & 49 \\
\hline
\end{tabular}

Source: Hai and Lien (2012)

published information scatteredly in different sections of their sites (for example, "News", "Operations News", etc.); this arrangement challenges information finders. Several companies designed a check list with full items, but there were no content when clicked. Some companies used free data transaction websites such as http://www.mediafire.com, so documents would be deleted after a storage time period or site closure. The survey also points out that just some companies considered website disclosure a provision in their charter/bylaws.

Thus, regarding the aspect of disclosure on official corporate website, corporate governance quality of companies listed in HNX is at medium level; most companies had not considered their corporate websites an official channel and had scatteredly disclosed information via that tool.

A description of the detailed information disclosed will further prove the above conclusion. Table 2 indicates that nearly half (171/396) of the companies disclosed none of the three reports surveyed; those companies belonged to three cases (Have no corporate website; Have a corporate website without corporate governance information; Have a corporate website with some corporate governance information but none of the three reports). Only 49 (of 396, equivalent to $12.37 \%$ ) companies disclosed all three reports. It is obvious that access to corporate governance information of HNX companies is limited.

The survey points out a high concentration of companies in big economic centers (158 in Hanoi, 59 in Ho Chi Minh City). However, the geographic allocation dominated by big centers does not mean that companies in big cities and provinces have better corporate governance than companies in other provinces. As evidence, among 49 companies publishing full three corporate governance reports in 2010, the geographic allocation was equal among provinces (even though the number of companies from big centers was still a bit greater). This indicates that corporate governance quality is equal among companies, without geographic or local economic development discrimination. 
Gov-score statistics will verify that the corporate governance quality is equal but at medium level among the companies.

Data from 49 companies showed that the minimum Gov-score was 24, the maximum of 28 and the mean of 25.73. The statistics suggest a narrow difference between companies. The gap between the maximum and the minimum was only 4 points (28 minus 24), and 31 among 49 companies possessed Gov-score of 25 or 26 points, accounting for $63.27 \%$ (Fig. 1 and Table 3).

Gov-score of the companies were approximate, so what creates the difference in their corporate governance quality? Eleven criteria explained for the difference; among them, the most important are: when and who approve auditors; directors' participation in board meetings; CEO's participation in board; percentage of outside independent directors in the board; the separation between the positions of CEO and Board chairman; the right of cumulative voting in the selection of directors and supervisory board members.

HNX companies select audit companies by two methods: the Annual General Shareholders Meeting approves them at the annual meeting or it authorizes the board of directors to select them after the annual meeting. $71.4 \%$ of the companies authorized the boards to select audit companies. This indicates that shareholders do not directly select; they had not fully used their rights and this is a negative signal of corporate governance quality.

Directors should attend at least $75 \%$ of board and committee meetings to effectively carry out their fiduciary duties (ISS 2003). The survey result is that $30.61 \%$ of the companies had directors who did not attend at least $75 \%$ of board meetings. They did not well present the shareholders' interest in 2010.

$38.78 \%$ of the companies had CEOs or former CEOs as directors. In nearly $40 \%$ of the companies, the CEO worked as a director; this is a limitation on board effectiveness and corporate governance quality in general. The situation was more popular in equitized SOEs in which directors representing state shares alternatively assume positions of CEO and board chairman in accordance with directives from the legal person or the organization they represent.

In $75.51 \%$ of the HNX companies, there were less than $50 \%$ of directors as outside independent directors. According to current regulations on listed companies, boards must include at least one third of outside independent directors. According to the original criteria for Gov-Score, directors are divided into three groups: inside

\begin{tabular}{|c|c|}
\hline Gov-Score & Percentage \\
\hline 24 & 14.29 \\
\hline 25 & 28.57 \\
\hline 26 & 34.69 \\
\hline 27 & 14.29 \\
\hline 28 & 8.16 \\
\hline
\end{tabular}

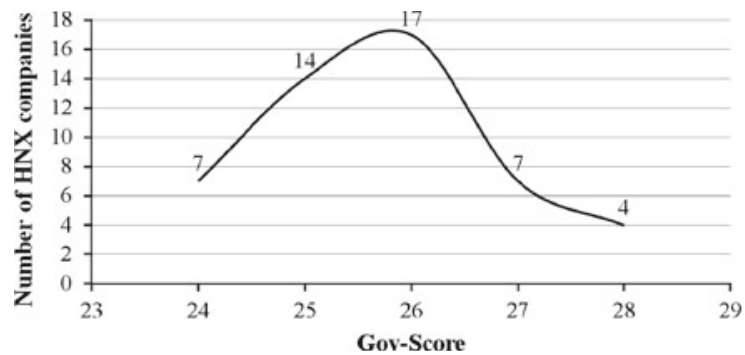

Fig. 1 Distribution of Gov-scores of companies listed on Hanoi stock exchange in 2010. Source: Hai and Lien (2012) 
Table 3 Statistics on Govscores of companies listed on Hanoi stock exchange

Source: Hai and Lien (2012)

\begin{tabular}{lc}
\hline Criteria & Score \\
\hline Mean Gov-score & 25.73 \\
Maximum Gov-score & 28.00 \\
Minimum Gov-score & 24.00
\end{tabular}

directors, affiliated directors and independent directors [(who have no connection to company other than board seat (ISS 2003)]. This standard is much higher than the current standards for independent directors in Vietnam. The Model Corporate Governance Bylaws for listed companies recommend that independent directors are not CEOs, vice CEOs, head accountants and other managers approved by the board or major shareholders of the company.

When standards for independent directors in the Model Corporate Governance Bylaws issued by the Ministry of Finance were used to test, the following results were found. Most companies satisfied the standard of one third non-executive directors. In general, a board with 5 directors includes 3 executives and 2 nonexecutives. More than three fourth of the companies did not satisfy the standard of $50 \%$ non-executive independent directors. Directors with relationships to management boards may not be ready or cannot effectively assess and supervise a company's strategy and performance. Furthermore, boards without enough independence from the management board may face conflicts of interest. The HNX companies meet the standard of independent directors trough "tricks" such as that directors are heads of a division, the position is not requiring approval by the board; and they may be manager of a member company, etc. In their nature, those directors are not independent. The evidence suggests that the standard of independent directors is almost not satisfied by HNX companies.

The percentage of companies with CEO/Chair separation $(56.06 \%)$ approximates that of companies without separation (46.94\%). "The positions of chairman and CEO are two distinct jobs with different job responsibilities. Some believe that having the same person holding the positions of chairman and CEO puts into question whether the board can adequately oversee and evaluate the performance of senior officers (including the CEO) and the company" (ISS 2003). While the answer is still ambiguous, the separation is considered to be better. In the case of Hanoi stock exchange, half of the companies have a combination of the two top positions, so a great power concentrates in such a person and the other shareholders are less listened to. In other words, the corporate governance quality is under satisfactory level.

Cumulative voting facilitates the election of minority representatives to the board. Cumulative voting is a corporate governance tool that shareholders can use to protect their interests. It is a means of giving shareholders access and influence over director elections (ISS 2003). Up to $77.55 \%$ of the surveyed companies did not have a provision on cumulative voting in their charter. Thus, shareholders' right is limited in many companies.

A remarkable point is that up to $89.8 \%$ of the companies did not have any directors attending corporate governance training courses (held by SSC). Only 5 of 
49 companies reported in their 2010 corporate governance reports that they had one to three directors participating in such courses. With the knowledge shortage in a new area like corporate governance, shareholders should not expect a perfect representation and perfect corporate governance by such directors.

All the above analysis leads us to one conclusion: corporate governance quality of companies listed on Hanoi stock exchange is at medium level on Gov-score scale.

Testing $H 2$ There is a high similarity among the listed companies in implementing a number of Gov-score criteria.

Hundred percent of the companies did not have a policy on annual audit rotation. All of them required a general shareholder meeting approval for filling board vacancies though the outgoing directors could have a temporary agreement during the waiting time. In addition, they required a supermajority voting to approve a charter amendment, a merger or acquisition and did not have any anti-takeover provisions in their charters.

Hundred percent of the companies defined board and supervisory term of 5 years; all directors and supervisory board members received compensation in form of cash or did not receive compensation (three companies did not pay directors due to loss in 2010 or they did not have a compensation policy).

Even though, boards are required to complete quarterly corporate governance reports and submit to SSC and Hanoi stock exchange, accompanied by quarterly financial report; $100 \%$ of the companies did not have any bylaws or internal regulations on director performance appraisal. In Model Corporate Governance Bylaws, there is a provision requiring companies to define regulations on performance review, promotion and demotion for directors, supervisory board members and management board executives and other managers (Ministry of Finance 2007). However, according to the data, there were no companies possessing such bylaws. In other words, there is no custom on director performance appraisal in these companies.

Hundred percent of the companies did not define a required retirement age for directors. The directors could be re-elected without limited terms. However, if a director represents for a legal person shareholder, he or she will automatically retire at the age regulated by Labour law.

The survey registered no cases in which outside independent directors held a meeting. Other criteria such as option repricing, share-compensation for directors, loans for directors or executives, etc. also reflect the same way of action by companies (they did not use).

Thus, the similarity is high among companies, but mostly on negative aspects; this represents low corporate governance quality.

So why did the HNX companies have the same performance on 28 criteria?

The first and most important cause is that the companies use almost all recommendations in the Model Charter for listed companies. In this way, they can most quickly satisfy requirements by SSC and the Exchange. The model charter was established based on international best practices in corporate governance, so by copying the model charter, the companies inherit many progressive provisions. The progressive practices recommended in the model charter helped the companies 
register points; but almost all companies did not apply other progressive practices hence no other points registered.

The second reason is that corporate governance for listed companies in Vietnam has developed just recently, for about some years. The companies have not experienced any crisis and serious losses caused by poor corporate governance problems, so they have not had internal demand for setting up internal corporate governance provisions that are suitable with their own features and industry characteristics.

Testing H3 The companies listed in Hanoi stock exchange have not implemented many progressive practices that go beyond current regulations recommended in the Model Charter for listed companies.

Analyzing in the section testing hypothesis two, inputs for 28 criteria showed absolute similarity among companies, because they all copied Model Charter and Model Corporate Governance Bylaws for listed companies. Besides the above regulations and activities, the similarity was also reflected in other aspects.

Among 49 companies, 48 used a required voting rate for approving shareholders' right amendment of $75 \%$ (like the Model Charter); only one required a different rate of $65 \%$ (HMH-Hai Minh Joint Stock Company).

$100 \%$ of the companies had a provision that supervisory board included three members and the members could be re-elected without limitation. They all had a provision that internal disputes would be settled by arbitrators or courts if negotiation had failed. No companies defined a prioritized method; they did not care about this legal aspect.

The survey records some differences from the model regulations. Such differences mostly come from regulations on directors, supervisory board, shareholders and shares. However, the differences are minor.

Thus, on Gov-score scale, HNX companies are at the medium level (25.73/51). Although they meet the requirements by current corporate governance and securities legislations in Vietnam; by nature, these standards are much lower than what required by Gov-score criteria. A remarkable characteristic of HNX companies is that they do not have a policy on auditor rotation and do not use board committees. Board size is relatively small (normally five members); this may be the reason why the companies do not use committees. Non-executive and independent directors usually are affiliated people or staffs who are not required to be approved by the board, so these directors are not totally independent. Voluntariness in disclosing corporate governance information via corporate website is not equal among companies. Only a small portion of the companies fully disclose. This is another limit in corporate governance of companies listed in Hanoi stock exchange.

The conclusion that corporate governance quality of HNX companies in particular and companies in Vietnam in general has received agreement from other research groups in Vietnam, of which the research by International Finance Corporation is the most remarkable.

Data in 2010 of 100 biggest listed companies in Vietnam (in both Hanoi stock exchange and Ho Chi Minh Stock Exchange) point out the mean corporate governance score of $44.7 \%$, only slightly better than the 2009 score of $43.9 \%$. Corporate governance awareness, understanding and application in the 100 largest 
listed companies in Vietnam is at a rudimentary stage. Companies have not recognized the message that good corporate governance brings them benefits and may positively affect profitability and performance (IFC 2011).

To sum up, low corporate governance quality is a common situation in Vietnam, and it requires basic and drastic solutions to improve.

\section{Solutions to Improving Corporate Governance Quality and Needs to Implementing University Corporate Governance Courses}

High corporate governance quality benefits various stakeholders; attract and persuade investors in securities and financial markets; create added values for shareholders; enhance market health and transparency; strengthen performance of state administrations and supply a more stable working environment for workers, etc. While the corporate governance quality of Vietnam companies is still low, the following solutions may improve it.

Consider Framework Improvement the Leverage for Enhancing Corporate Governance Quality at Company Level

First, more rigorously administer listed companies. Listed companies can be administered most easily because of the requirements they have to follow in order to continue listing. If we can raising corporate governance quality of this group, it will be a good premise to strengthen corporate governance quality of other public companies in general.

Officially, all listed companies are required to complete all types of reports; however, the quality of the reports or the information needs to be improved.

Since the issuance of model charter, annual report and corporate governance report regulations, SSC and the Exchanges have encouraged companies to follow. The time frame of 4 years is enough for companies to rehearse, and now it is time for SSC and the Exchanges to force the companies to supply high quality reports. Companies with late submission and poor report should be punished. SSC and the Exchanges should review and grade reports as a compulsory rule. In annual reports, companies mostly focus on income and finance; information of important peoples is inadequate, especially of their relationship with other companies and organizations. Without this information, there is no evidence to assess if they have a relation with related parties or not.

Another procedure that needs to be more rigorously enforced is the corporate governance bylaws that are copies of the Model Bylaws. SSC should require companies to establish their typical bylaws with full regulations that can be enacted immediately without further guidance. To achieve that goal, SSC should require companies to complete the bylaws with full processes and procedures for: review, promotion and demotion of directors, supervisory board members, executives and other managers; selecting, appointing and dismissing top executives; coordinating activities of board, supervisory board and management board; organizing board meetings and nominating, selecting, appointing and dismissing directors. 
Current charters have some general provisions on these processes and procedures; however, they should put more details into their corporate governance bylaws. Then, potential shareholders will have sufficient information of important policies and be able to assess corporate governance quality before making an investment decision.

Furthermore, listed companies should be required to make a compulsory disclosure on their own websites.

The responsibility of more rigorous administration falls on the Ministry of Finance, SSC and the Exchanges.

Second, the Ministry of Finance and State Securities Commission should consider raising minimum corporate governance requirements by amending the current model bylaws and charter. The two agencies should raise standards for independent directors. Besides they are non-executives, the directors should ensure independence from major shareholders, major partners with important influence on the companies. In addition, the rate of independent directors should be raised also.

The agencies should clarify their view on situations in which one company hires an audit company for a long time; the company should disclose if they have interest relationship via related or member companies.

\section{Promote Corporate Governance Education for All Related Groups}

First, corporate governance education should be designed for targeted groups including directors, management boards, supervisory boards, shareholders and related parties. Shareholders need to be trained or self-study to fully understand their rights and duties, what they can do and cannot do and how to express their opinions on important issues, etc. Directors and supervisory board members should be trained on duties of a shareholders' representative, an intermediary between owners and executives. Management board or top executives should be trained to understand expectations and ways of behaving of the owners, and learn how to appropriately act in such an environment. Other stakeholders should have minimum understanding of how they could be affected by related parties and how to act in case of transactions with related parties in order to secure best benefits.

One group who acts as a catalyst for corporate governance development from its foundation are journalists. They affect the public point of view on corporate governance via news and articles. Thus, the journalists should be trained to understand fundamentals of corporate governance so that they can correctly issue news and enhance society's understanding.

Second, training courses should be designed in accordance with the needs of each targeted group. A general course on general regulations on corporate governance is necessary for all groups, especially journalists. Directors and supervisory board members need more specialized courses.

Current regulations require directors to complete a compulsory course on corporate governance held by training centers that receive authority from SSC. The survey draws a cloudy picture of this practice; only three of forty nine companies announced in their annual reports that they had directors or supervisory board members participate in such course and receive certificates. Furthermore, current courses are 
not designed with sufficient specialization for directors. SSC should more rigorously supervise the conformation with this requirement and improve training courses.

Third, besides compulsory courses with certificates by SSC, corporate governance training should be combined with other courses on finance or accounting. If we do this, learners will find it easier to understand the context and content of corporate governance. Materials on corporate governance fundamentals should be delivered widely via paper-based documents and Internet so that all people with interest can access. Corporate governance training centers should be developed; SSC's training center should play the role of an independent quality testing agency and the sole agency with authority to issue certificates and should not hold trainings.

Shareholders with full knowledge thanks to training will be the direct propellant to force companies to raise their corporate governance quality, and this is the sole way to reach high-quality and sustainable corporate governance.

\section{Corporate Governance Education for Business Undergraduates}

The above solutions are aimed at targeting people currently associated with corporate governance. However, experience and typical Vietnamese culture point out that it takes a very long time to make minor change in these stakeholders. Why is that? Those people have strong life and business experience; they have achieved considerable success and formed their business style. As a result, they are highly conservative. In addition, corporate governance law amendments requires a long time. Once business persons are not required by laws to implement good corporate governance, they will not do, since they can get much more profits with poor corporate governance. In other word, it is not wise to expect that we can change the current business persons to create good corporate governance. Instead, we may get more efficiency if we focus our efforts on educating a future generation with deep understanding of corporate governance before they enter markets. Therefore, the author recommends to make corporate governance a compulsory subject for all business undergraduates (including business administration, accounting, finance, banking, auditing students) when they enter the final school year.

This course should introduce fundamentals of corporate governance, the difference between corporate governance and business administration; the nature, structure and mechanisms of fundamental corporate governance structure; the nature, usage and how to use tools for corporate governance; and characteristics of corporate governance in Vietnam.

Such a corporate governance course will supply foundation knowledge for future shareholders, institutional investors, top executives and even corporate secretaries. Along with framework reforms, the courses may create a fundamental change in corporate governance in Vietnam in 10-15 years.

\section{Conclusion}

Currently, corporate governance quality of companies in Vietnam is at medium level on Gov-score scale; the companies have not gone beyond minimum 
requirements by current regulations. In this context, the two key solutions to raise quality are enhancing framework reforms and focusing on corporate governance education and training. Especially, investing in corporate governance training for business undergraduates is the fundamental prescription, because it creates a future generation of investors, executives and leaders with deep knowledge and knowing how to act appropriately under pressure of a more rigorous legitimate system on corporate governance. If implemented, it is expected that the solutions will considerably improve corporate governance quality in Vietnam in 10-15 years.

\section{References}

Brown LD, Caylor ML (2006) Corporate governance and firm valuation. J Account Public Policy 25:409-434. http://papers.ssrn.com/sol3/papers.cfm?abstract_id=754484\#\#. Accessed 10 Jan 2010

Hai HV, Lien TTH (2012) Research project report. An assessment on corporate governance quality of joint stock companies listed on Hanoi stock exchange based on Gov-score criteria. Code QK10.13, University of Business and Economics, Vietnam National University-Hanoi, Hanoi

IFC (2011) Vientam Corporate Governance Scorecard Report. http://www.ifc.org/ifcext/mekongpsdf.nsf/ Content/CG-Pubs. Accessed 15 July 2012

Institutional Shareholder Services (ISS) (2003) ISS corporate governance: best practices user guide \& glossary. http://www.issproxy.com/. Accessed 9 Jan 2010

Japan Corporate Governance Research Institute (JCGR) (2003) Report on the 2003 corporate governance index survey. http://www.jcgr.org/eng/survey/pdf/report2003eng.pdf. Accessed on 9 Jan 2010

Lien TTH (2008) The impact of corporate governance on corporate performance-The Case of Vietnam-Italy Steel Joint Stock Company. Dissertation, National Economics University, Hanoi

Ministry of Finance (2007) Model corporate governance bylaws for listed companies. Hanoi. http:// www.hsx.vn/hsx/Modules/Phapquy/Phapquy.aspx. Accessed 20 July 2012

The World Bank (2006) Report on the observance of standards and codes (ROSC) - Vietnam. http:// www.worldbank.org/ifa/rosc_cg_vm.pdf. Accessed 30 Dec 2009 